\title{
New Method for Removal of Organic Dyes Using Supported Iron Oxide as a Catalyst
}

\author{
Samia A. Kosa, ${ }^{1}$ Naha M. Al-sebaii, ${ }^{1}$ Islam H. Abd El Maksod, ${ }^{1,2}$ and Eman Z. Hegazy ${ }^{1,2}$ \\ ${ }^{1}$ King Abdulaziz University, P.O. Box 42805, Jeddah, Saudi Arabia \\ ${ }^{2}$ Physical Chemistry Department, National Research Centre, Dokki, Cairo 12311, Egypt \\ Correspondence should be addressed to Eman Z. Hegazy; ehegazy77@yahoo.com
}

Received 12 September 2015; Revised 26 November 2015; Accepted 29 November 2015

Academic Editor: Wenshan Guo

Copyright (c) 2016 Samia A. Kosa et al. This is an open access article distributed under the Creative Commons Attribution License, which permits unrestricted use, distribution, and reproduction in any medium, provided the original work is properly cited.

\begin{abstract}
In this study, we perform a catalytic decomposition of organic dye over $\mathrm{Fe}_{2} \mathrm{O}_{3}-\mathrm{CeO}_{2}-\mathrm{TiO}_{2}-\gamma-\mathrm{Al}_{2} \mathrm{O}_{3}$ catalyst in the presence of molecular oxygen and chlorate ions. The results showed that organic dye acts as a sensitizer during this process. The mechanism of the allover process is hypothesized. Several techniques were employed for the characterization of the catalyst, including XRD, SEM, EDAX, and thermal analysis and catalytic activity. The analysis showed that iron is the main active centers, and we have two types of active centers in this process: surface iron and dissolved iron in titanium dioxide. The dissolved iron was found to be the most active center; however, after $\mathrm{Fe} / \mathrm{Ti}=2.76$, a synergism was observed to be occurring between the two active centers.
\end{abstract}

\section{Introduction}

Organic dyes are used in a wide range of industrial applications [e.g., textiles (the most significant), food products, cosmetics, pharmaceuticals, and paper printing], which means that they are frequently found in industrial wastewater. Several groups of dyes can be distinguished on the basis of their compound structure (e.g., phthalocyanines, anthraquinones, quinone imines, and xanthenes) $[1,2]$. However, azo dyes are considered most effective and easier to use in industrial applications than dyes from natural sources. The production of azo dyes in 2003 reached more than $7 \times 10^{5}$ tons [1]. The toxicity of azo dyes has two different aspects: its own toxicity to living organisms and toxicity through the reflection of sunlight, which mainly affects living organisms in a water environment. In addition, aesthetic issues could arise from the coloring of the water by these dyes $[2,3]$. There is substantial research interest in these drawbacks of the use of azo dyes: many efforts have been devoted to developing methods of degradation of such dyes and to validating analytical methods for these processes.

Among all industries using dyes, the textile industry is considered to use the highest amount of dyes in terms of both amount and variety. Thus, wastewater generated by the textile industry generally contains a high content of large aromatic compounds in addition to toxic materials such as azo dyes, which are also considered to be highly carcinogenic [4]. Wastewater is contaminated annually by $14-15 \%$ of total azo dye production. Even the discharge of dyes in small amounts (less than 1 PPM) affects living organisms through the reflection of sunlight, cutting off the food chain of many other aquatic organisms. The complexity of removal arises from the presence of nonbiodegradable organic molecules, with many of them being toxic, in the wastewater released from this industry. The conventional methods of removal, including fluctuation, coagulation, and adsorption of color through membranes, have many drawbacks and could rerelease the dyes into the wastewater. An efficient tertiary treatment is needed to remove all these contaminants [5].

Azo dyes are the main source of contaminants among all other dyes used [6-8]. The color raised in many azo dyes is from an $\mathrm{N}=\mathrm{N}$ bond combined with the chromosphere, which increases the difficulty of its degradation $[9,10]$. Hence, as previously stated, the inability of conventional methods to completely remove all pollutants and their risk resulting in secondary pollutants indicates an urgent need to develop a new removal method $[11,12]$. 


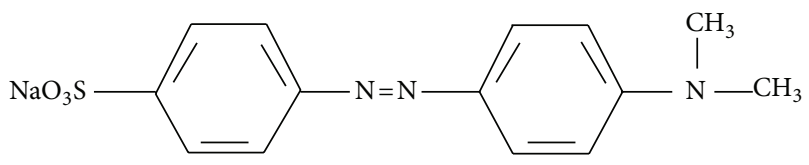

FIGURE 1: Chemical structures of methyl orange.

As the total removal of such organic pollutants, in contrast to inorganic ones, is almost impossible using adsorption techniques [13-16], it is essential to develop a catalytic decomposition technique to completely remove such pollutants [1722]. The commonly used photocatalytic decomposition in this process has a limitation in that it cannot be enlarged to the industrial scale due to the prohibitively large application of UV irradiation $[17,18]$. The catalytic decomposition of organic dye using ecofriendly oxidants such as hydrogen peroxide is also used; however, hydrogen peroxide considered a mild oxidant, and hence decomposition may not be complete, resulting in secondary more dangerous pollutants [23]. The generation of nascent atomic oxygen may be more efficient in such processes in achieving total decomposition of the organic pollutant. Such reactions usually occur in only a few minutes via a free radical mechanism.

In this paper, we will discuss the use of a $\mathrm{Fe} / \mathrm{Ce} / \mathrm{Ti} / \mathrm{alu}-$ mina system in the presence of molecular oxygen and perchlorate solution. It is supposed that, in such a system, the organic dye itself will act as a sensitizer to generate nascent oxygen. A comprehensive surface study will be performed to recognize the types of active centers and determine the mechanism of decomposition.

\section{Experimental}

2.1. Materials. All chemicals used for the preparation of $\mathrm{Fe}_{2} \mathrm{O}_{3}-\mathrm{CeO}_{2}-\mathrm{TiO}_{2}-\gamma-\mathrm{Al}_{2} \mathrm{O}_{3}, \mathrm{Fe}_{2} \mathrm{O}_{3}-\mathrm{La}_{2} \mathrm{O}_{3}-\mathrm{TiO}_{2}-\gamma-\mathrm{Al}_{2} \mathrm{O}_{3}$, and $\mathrm{CuO} / \mathrm{CeO}_{2}-\mathrm{TiO}_{2}$ were analytical grade reagents. The catalyst carrier was $\gamma-\mathrm{Al}_{2} \mathrm{O}_{3}(\varphi=2-3 \mathrm{~mm})$. An azo dye, methyl orange, was chosen as the target compound, and its chemical structure is as shown in Figure 1. The following high purity raw materials were used:

(i) titanium (IV) tetraisopropoxide, 98\%, $\mathrm{C}_{12} \mathrm{H}_{28} \mathrm{O}_{4} \mathrm{Ti}$, ACROS Organics Laboratories Supplies [New Jersey, USA],

(ii) ferric nitrate, $\mathrm{Fe}\left(\mathrm{NO}_{3}\right)_{3} \cdot 9 \mathrm{H}_{2} \mathrm{O}$, Fluka-Garantie,

(iii) cerium (IV) ammonium sulfate, $\left(\mathrm{NH}_{4}\right)_{4} \mathrm{Ce}\left(\mathrm{SO}_{4}\right)_{4}$. $2 \mathrm{H}_{2} \mathrm{O}$, Fluka AG [Switzerland],

(iv) copper (II) nitrate, $\mathrm{Cu}\left(\mathrm{NO}_{3}\right)_{2} \cdot 21 / 2 \mathrm{H}_{2} \mathrm{O}$, SigmaAldrich,

(v) titanium tetrachloride, $\mathrm{TiCl}_{4}$, Fluka AG,

(vi) ammonium cerium (IV) nitrate, 99\%, $\mathrm{H}_{8} \mathrm{CeN}_{8} \mathrm{O}_{18}$, ACROS Organics [New Jersey, USA],

(vii) titanium (IV) oxide, anatase, -325 mesh, >99\% metal basis, Sigma-Aldrich,

(viii) lanthanum (III) nitrate hexahydrate, 99.999\%, ACROS Organics [New Jersey, USA], (ix) oxygen gas $(99.999 \%)$,

(x) aluminum hydroxide, $\mathrm{Al}(\mathrm{OH})_{3}$, Laboratories Supplies Ltd. [Colebrook Buck, UK],

(xi) sodium hypochlorite solution (commercial),

(xii) sodium hydroxide, $\mathrm{NaOH}$, Sigma-Aldrich,

(xiii) catalyst: nitric acid, $\mathrm{HNO}_{3}, \mathrm{BDH}$ [Poole, UK],

(xiv) solvent: absolute ethanol, $\mathrm{C}_{2} \mathrm{H}_{5} \mathrm{OH}, 96 \% \mathrm{v} / \mathrm{v}, \mathrm{BDH}$ [Poole, UK],

(xv) Methyl Orange Indicator, Pacegrove Limited [UK].

\subsection{Procedure and Apparatus}

2.2.1. Preparation of $\mathrm{Fe}_{2} \mathrm{O}_{3}-\mathrm{CeO}_{2}-\mathrm{TiO}_{2}-\gamma-\mathrm{Al}_{2} \mathrm{O}_{3}$. $\mathrm{Fe}_{2} \mathrm{O}_{3}-\mathrm{CeO}_{2}-$ $\mathrm{TiO}_{2}-\gamma-\mathrm{Al}_{2} \mathrm{O}_{3}$ was prepared by consecutive impregnation. Three samples were prepared from this catalyst with different chemicals used in the preparation of each type.

Preparation of the first type of catalysis samples at different concentrations of iron nitrate.

A precursor of $\mathrm{TiCl}_{4}$ was added dropwise to $50 \mathrm{~mL}$ absolute ethanol contained with $0.5 \mathrm{~g}$ cerium ammonium sulfate under vigorous stirring, and a small amount of deionized water and nitric acid was added to the mixture drop by drop. The volume ratio of $\mathrm{TiCl}_{4}$ to distilled water was $4: 1$. Twenty grams of $\gamma-\mathrm{Al}_{2} \mathrm{O}_{3}$ carrier was added to the above mixture stirring for $1 \mathrm{~h}$ at room temperature, and the samples were dried at $80^{\circ} \mathrm{C}$ for $10 \mathrm{~h}$ and then at $110^{\circ} \mathrm{C}$ for $2 \mathrm{~h}$. The dried samples were calcined at $450^{\circ} \mathrm{C}$ for $2 \mathrm{~h}$ in an oven to obtain the intermediate $\mathrm{CeO}_{2}-\mathrm{TiO}_{2}-\gamma-\mathrm{Al}_{2} \mathrm{O}_{3}$; $\mathrm{Fe}$ was then loaded on $\mathrm{CeO}_{2}-\mathrm{TiO}_{2}-\gamma-\mathrm{Al}_{2} \mathrm{O}_{3}$ by the impregnation of $\mathrm{CeO}_{2}-\mathrm{TiO}_{2}-$ $\gamma-\mathrm{Al}_{2} \mathrm{O}_{3}$ in $100 \mathrm{~mL}$ aqueous solution containing (variable) $\mathrm{mol} / \mathrm{L}$ of $\mathrm{Fe}\left(\mathrm{NO}_{3}\right)_{3}$ for $12 \mathrm{~h}$ under room conditions, and upon the completion of the same drying process; the dried samples were calcined at $350^{\circ} \mathrm{C}$ for $3 \mathrm{~h}$, thus obtaining the $\mathrm{Fe}_{2} \mathrm{O}_{3}$ $\mathrm{CeO}_{2}-\mathrm{TiO}_{2}-\gamma-\mathrm{Al}_{2} \mathrm{O}_{3}$ catalyst, as shown in Table 1 .

2.2.2. Characterization Techniques and Control Test. The produced samples were evaluated and characterized by determining surface area, particle size, and phase analysis by XRD, UV-Vis, SEM, EDAX, ESR, and DSC, as follows.

(1) X-Ray Powder Diffraction Analysis (XRD). The crystalline phase and crystallite size of all catalyst nanoparticle samples were analyzed by X-ray powder diffraction (XRD) measurements which were performed using a Rigaku X-ray diffractometer system equipped with a RINT 2000 wide angle Goniometer using $\mathrm{Cu} K \alpha$ radiation $(\lambda=0.15478 \mathrm{~nm})$ and a power of $40 \mathrm{kV} \times 30 \mathrm{~mA}$. The intensity data were collected at room temperature over $2^{\circ}$ intervals ranging from 10 to $80^{\circ}$.

(2) Ultraviolet-Visible Spectroscopy (UV-Vis). UV-Vis electronic absorption spectra were recorded by MultiSpec-1501 spectrometer between 180 and $800 \mathrm{~nm}$ using a quartz cell $(1.0 \mathrm{~cm})$.

(3) Scanning Electron Microscopy (SEM) Observation and $E D A X$. Scanning electron microscopy (SEM) images were 
TABLE 1: Different amounts of iron nitrate, cerium ammonium sulfate, and titanium tetrachloride.

\begin{tabular}{lcccc}
\hline Sample & $\begin{array}{c}\text { Concentrations of iron nitrate } \\
(\mathrm{mol} \backslash \mathrm{L})\end{array}$ & $\begin{array}{c}\text { Amount of iron nitrate } \\
(\mathrm{g})\end{array}$ & $\begin{array}{c}\text { Amount of titanium } \\
\text { tetrachloride }\end{array}$ & $\begin{array}{c}\text { Amount of cerium } \\
\text { ammonium sulphate }\end{array}$ \\
\hline $\mathrm{la}$ & 0.1 & 4.04 & & \\
$\mathrm{lb}$ & 0.5 & 20.2 & $4 \mathrm{~mL}$ & $0.5 \mathrm{~g}$ \\
$\mathrm{lc}$ & 1 & 40.4 & & \\
$\mathrm{ld}$ & 1.5 & 60.6 & & \\
\hline
\end{tabular}

TABLE 2: Different weight \% of oxide form all samples in series 1 and catalytic activity response.

\begin{tabular}{|c|c|c|c|c|c|c|}
\hline \multirow{2}{*}{ Series one } & \multicolumn{4}{|c|}{ Weight percent (\%) } & \multirow{2}{*}{ (Time to reach $100 \%$ degradation, min) } & \multirow{2}{*}{ Catalytic activity response } \\
\hline & $\mathrm{Fe}_{2} \mathrm{O}_{3}$ & $\mathrm{CeO}_{2}$ & $\mathrm{TiO}_{2}$ & $\gamma-\mathrm{Al}_{2} \mathrm{O}_{3}$ & & \\
\hline la & 3.3 & 0.61 & 12.07 & 83.98 & 20 & 0.05 \\
\hline $1 b$ & 14.6 & 0.53 & 10.66 & 74.18 & 5 & 0.2 \\
\hline $1 c$ & 25.7 & 0.46 & 9.28 & 64.54 & 3 & 0.333333 \\
\hline $1 \mathrm{~d}$ & 33.99 & 0.41 & 8.25 & 57.39 & 2 & 0.5 \\
\hline
\end{tabular}

collected and EDAX analysis was performed using a JXA-840 Electron Probe Micro Analyzer (JEOL).

(4) Differential Scanning Calorimetry (DSC) and TGA. Thermogravimetric analysis (TGA) and differential scanning calorimetric (DSC) analysis were performed by heating in a current of $\mathrm{N}_{2}$ flowing at a rate of $20 \mathrm{~mL} / \mathrm{min}$ using an SDT Q600 thermal analyzer with a heating rate of $13^{\circ} \mathrm{C} \cdot \mathrm{min}^{-1}$.

(5) Electron Spin Resonance (ESR). The ESR spectra were used using a Bruker EMX-500 operated at $\mathrm{x}$-band frequency with a sweep width of $6000 \mathrm{G}$.

(6) Total Organic Carbon (TOC). Organic carbon content was measured using a Multi N/C total organic carbon measurement instrument (Analytik Jena, model 2100/2100 S).

2.3. Catalytic Decomposition of Organic Dyes. Catalytic decomposition of organic dye was performed by passing $\mathrm{O}_{2}$ gas on the solution of a dye with chlorate solution after which the catalyst was added as shown in Figure 2. Time to reach $100 \%$ degradation was used as a measure of catalytic activity.

2.4. Calculation of Catalytic Activity Response. Catalytic activity responses were calculated by 1st obtaining the reciprocal of time to $100 \%$ degradation as a response to catalytic activity. To study the effect of any component in the presence of each other, we divide the catalytic activity response on $\%$ composition of all components in the composite except the one being studied, as shown in Tables 1-7.

\section{Results and Discussion}

3.1. Characterization of Catalyst. In catalyst characterization, knowledge of the catalyst's texture as well as its phase and chemical compositions represents an essential minimum. XRD pattern, DSC, SEM micrograph and EDX, ESR, and $\mathrm{UV}-\mathrm{Vis}$ spectrum are basic methods providing the required information.

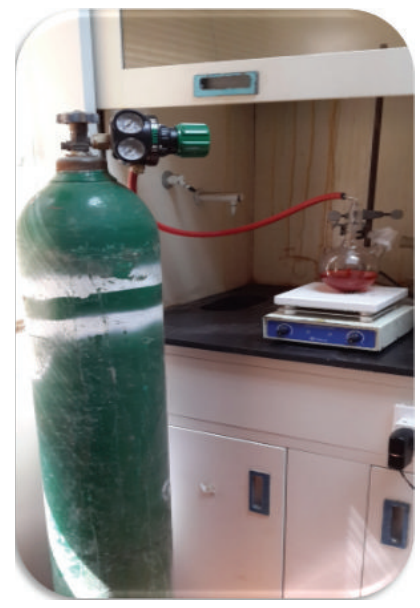

FIGURE 2: System of catalytic decomposition of organic dyes.

TABLE 3: Effect of $\mathrm{Fe}_{2} \mathrm{O}_{3}$.

\begin{tabular}{lc}
\hline $\mathrm{Fe}_{2} \mathrm{O}_{3}$ & Catalytic activity response \\
\hline 3.3 & $8.08643 E-05$ \\
14.6 & 0.000477211 \\
25.7 & 0.001209885 \\
33.99 & 0.002575704 \\
\hline
\end{tabular}

TABLE 4: Effect of $\mathrm{CeO}_{2}$.

\begin{tabular}{lc}
\hline $\mathrm{CeO}_{2}$ & Catalytic activity response \\
\hline 0.61 & $1.49477 E-05$ \\
0.53 & $1.73234 E-05$ \\
0.46 & $2.16555 E-05$ \\
0.41 & $3.10691 E-05$ \\
\hline
\end{tabular}

3.1.1. XRD Analysis. The XRD patterns (Figure 3) show the crystalline phases of $\mathrm{TiO}_{2}, \gamma-\mathrm{Al}_{2} \mathrm{O}_{3}$, and $\mathrm{Fe}_{2} \mathrm{O}_{3}$, respectively. It is observed that, at low concentrations of iron, $\mathrm{Fe}_{2} \mathrm{O}_{3}$ did 


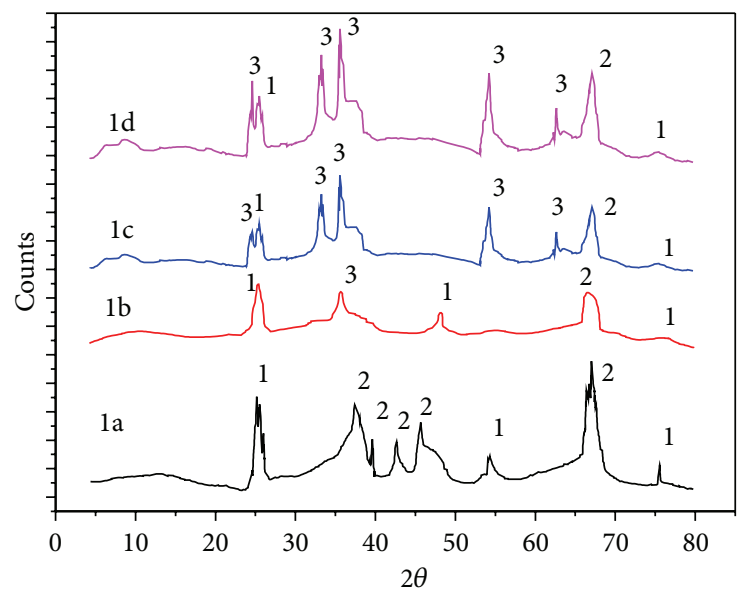

(1) $\mathrm{TiO}_{2}$

(2) $\mathrm{Al}_{2} \mathrm{O}_{3}$

(3) $\mathrm{Fe}_{2} \mathrm{O}_{3}$

FIGURE 3: XRD patterns of series 1 samples.

TABLE 5: Effect of $\mathrm{TiO}_{2}$.

\begin{tabular}{lc}
\hline $\mathrm{TiO}_{2}$ & Catalytic activity response \\
\hline 12.07 & 0.000295767 \\
10.66 & 0.000348429 \\
9.28 & 0.000436877 \\
8.25 & 0.000625171 \\
\hline
\end{tabular}

TABLE 6: Effect of $\gamma-\mathrm{Al}_{2} \mathrm{O}_{3}$.

\begin{tabular}{lc}
\hline$\gamma-\mathrm{Al}_{2} \mathrm{O}_{3}$ & Catalytic activity response \\
\hline 83.98 & 0.002057875 \\
74.18 & 0.002424622 \\
64.54 & 0.003038364 \\
57.39 & 0.004348916 \\
\hline
\end{tabular}

not appear; however, as the amount of $\mathrm{Fe}_{2} \mathrm{O}_{3}$ increased, a diffraction peak of $\mathrm{Fe}_{2} \mathrm{O}_{3}$ increased consequently.

3.1.2. TGA and DSC Analysis. The thermal analysis curve (Figure 4) showed that the precursor decomposition of all samples was complete at $400^{\circ} \mathrm{C}$, which was chosen as the final calcination temperature for all samples.

(1) Effect of Each Species Added on Catalytic Activity. Figures 5-7 show the relationship between each species and the catalytic activity response divided by the complementary percentage of the other components to evaluate the response of catalytic activity to other species.

From these figures, we can recognize the effect of each species regardless of the others with respect to $\mathrm{Fe}_{2} \mathrm{O}_{3}$ species as the percentage of $\mathrm{Fe}_{2} \mathrm{O}_{3}$ increases and normalized catalytic activity response increases, while for the species $\mathrm{Ce}, \mathrm{Al}$, and $\mathrm{Ti}$, catalytic activity decreases with increasing percentage, indicating that the catalytic active centers in this process are mainly Fe species. However, to study the effect of each species

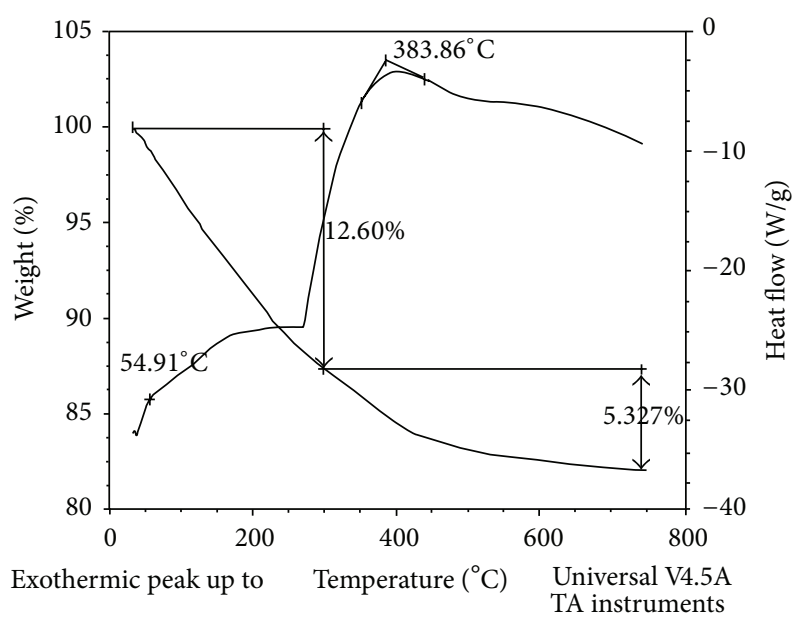

Figure 4: TGA and DSC of la sample.

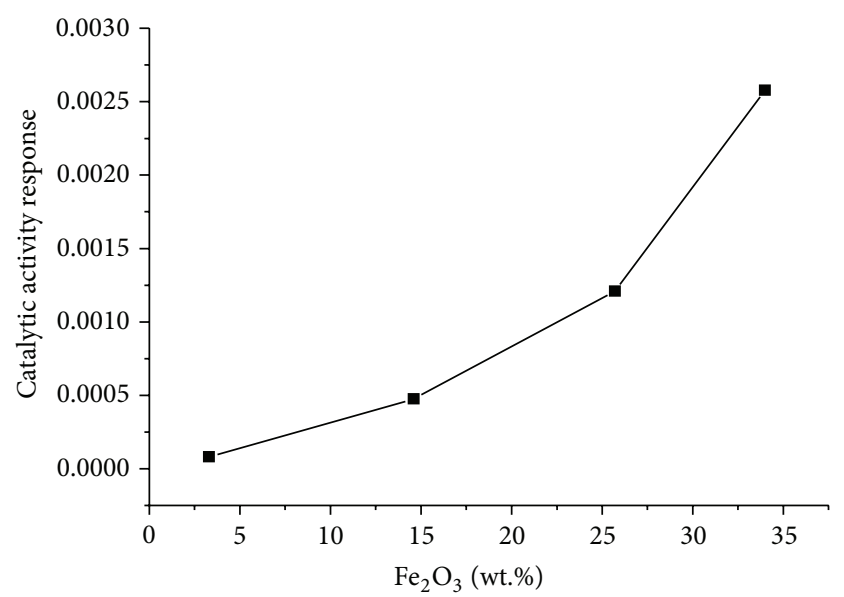

FIGURE 5: Effect of different wt.\% of $\mathrm{Fe}_{2} \mathrm{O}_{3}$ on catalytic activity response in series 1 .

on the catalytic activity per unit iron we plot normalized activity of each species divided by $\%$ of iron oxide against $\%$ of each species (Figure 12). From this figure we can recognize that as the $\%$ of these species increases the catalytic activity of one active species of iron increases. Moreover, this increase is inversely proportional to the amount of iron and showed nonlinear increase behavior with inversion point at $\%$ of iron oxide $=14.6$. If we correlate this with surface excess concentration of iron (Figure 13), we can find that as the surface excess concentration of iron increases the effect of $\mathrm{CeO}_{2}, \mathrm{TiO}_{2}$, and alumina is maximized for enhancement of the catalytic activity of iron which give impression that there are more than one active center of iron oxide present which will be clarified in the EDX section.

(2) SEM and EDX Analysis. Figures 8-11 show the SEM of our samples. These figures show an SEM image of samples la-1d and clearly reveals an agglomerated white background with some distributed dark areas, which could be iron oxide distributed on $\mathrm{TiO}_{2}$ and $\mathrm{Al}_{2} \mathrm{O}_{3}$. This interpretation could be confirmed by calculating the elemental analysis 
TABLE 7: Composition of series 1 samples with its catalytic activity.

\begin{tabular}{|c|c|c|c|c|c|c|c|}
\hline \multirow{2}{*}{ Key } & \multirow{2}{*}{ Composition } & \multirow{2}{*}{ Precursor for salt } & \multirow{2}{*}{ Time for complete decomposition } & \multicolumn{4}{|c|}{ Weight percent (\%) } \\
\hline & & & & $\mathrm{Fe}_{2} \mathrm{O}_{3}$ & $\mathrm{CeO}_{2}$ & $\mathrm{TiO}_{2}$ & $\gamma-\mathrm{AL}_{2} \mathrm{O}_{3}$ \\
\hline la & \multirow{4}{*}{$\mathrm{Fe}_{2} \mathrm{O}_{3}-\mathrm{CeO}_{2}-\mathrm{TiO}_{2}-\gamma-\mathrm{Al}_{2} \mathrm{O}_{3}$} & $\mathrm{Fe}\left(\mathrm{NO}_{3}\right)_{3}$ & $20 \mathrm{~min}$ & 3.3 & 0.61 & 12.07 & 83.98 \\
\hline $1 b$ & & $\left(\mathrm{NH}_{4}\right)_{4} \mathrm{Ce}\left(\mathrm{SO}_{4}\right)_{4}$ & $5 \mathrm{~min}$ & 14.6 & 0.53 & 10.66 & 74.18 \\
\hline $1 \mathrm{c}$ & & $\mathrm{TiCl}_{4}$ & $3 \mathrm{~min}$ & 25.7 & 0.46 & 9.28 & 64.54 \\
\hline $1 \mathrm{~d}$ & & $\mathrm{Al}(\mathrm{HO})_{3}$ & $2 \mathrm{~min}$ & 33.99 & 0.41 & 8.25 & 57.39 \\
\hline
\end{tabular}

TABLE 8: EDAX analysis with surface excess concentration.

\begin{tabular}{|c|c|c|c|c|c|c|c|c|}
\hline \multirow{3}{*}{ Sample } & \multicolumn{8}{|c|}{ Surface excess concentration } \\
\hline & \multicolumn{2}{|c|}{$\mathrm{Fe}_{2} \mathrm{O}_{3}$} & \multicolumn{2}{|c|}{$\mathrm{CeO}_{2}$} & \multicolumn{2}{|c|}{$\mathrm{TiO}_{2}$} & \multicolumn{2}{|c|}{$\gamma-\mathrm{Al}_{2} \mathrm{O}_{3}$} \\
\hline & Theoretical & Actual & Theoretical & Actual & Theoretical & Actual & Theoretical & Actual \\
\hline \multirow{2}{*}{ la } & 3.30 & 17.58 & 0.61 & 0.00 & 12.07 & 77.49 & 83.98 & 4.93 \\
\hline & \multicolumn{2}{|c|}{432.85} & \multicolumn{2}{|c|}{0.00} & \multicolumn{2}{|c|}{542.01} & \multicolumn{2}{|c|}{-94.13} \\
\hline \multirow{2}{*}{$1 \mathrm{~b}$} & 14.60 & 42.07 & 0.53 & 0.00 & 10.66 & 8.25 & 74.18 & 49.68 \\
\hline & \multicolumn{2}{|c|}{188.16} & \multicolumn{2}{|c|}{0.00} & \multicolumn{2}{|c|}{-22.61} & \multicolumn{2}{|c|}{-33.03} \\
\hline \multirow{2}{*}{ 1c } & 25.70 & 40.73 & 0.46 & 0.00 & 9.28 & 41.89 & 64.54 & 17.38 \\
\hline & \multicolumn{2}{|c|}{58.49} & \multicolumn{2}{|c|}{0.00} & \multicolumn{2}{|c|}{351.43} & \multicolumn{2}{|c|}{-73.08} \\
\hline \multirow{2}{*}{$1 d$} & 33.99 & 73.80 & 0.41 & 0.00 & 8.25 & 13.37 & 57.39 & 12.84 \\
\hline & \multicolumn{2}{|c|}{117.11} & \multicolumn{2}{|c|}{0.00} & \multicolumn{2}{|c|}{62.01} & \multicolumn{2}{|c|}{-77.63} \\
\hline
\end{tabular}

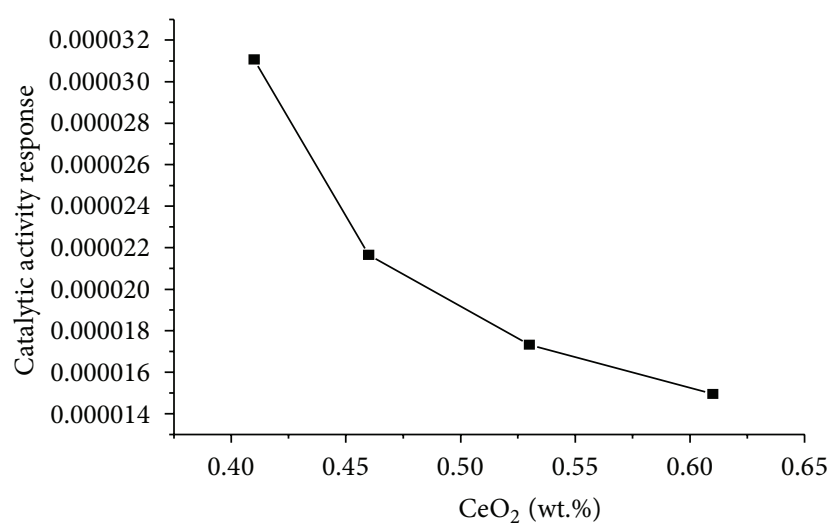

Figure 6: Effect of different wt.\% of $\mathrm{CeO}_{2}$ on catalytic activity response in series 1 .

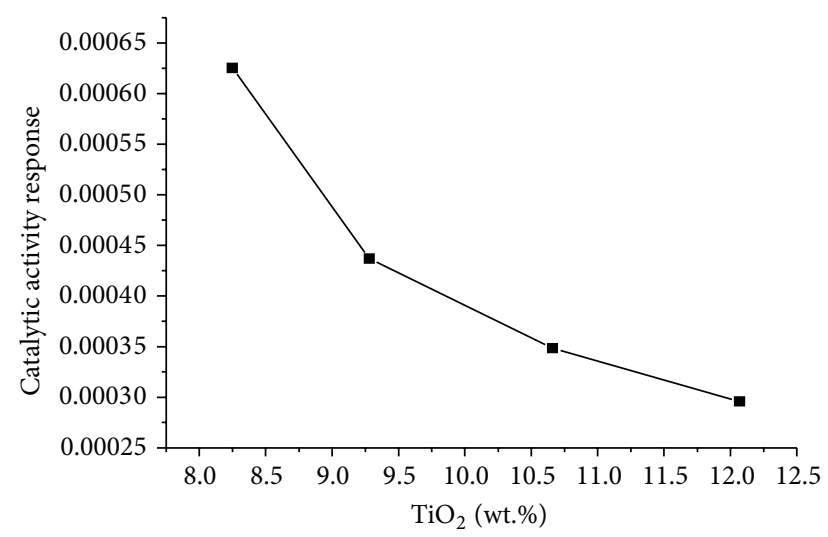

FIgURE 7: Effect of different wt.\% of $\mathrm{TiO}_{2}$ on catalytic activity response in series 1 . of the surface excess elements over the theoretical values determined from the EDAX analysis in Table 8 (table analysis EDAX). From these analyses, we can see that $\mathrm{TiO}_{2}$ and $\mathrm{Fe}_{2} \mathrm{O}_{3}$ are concentrated on the surface.

Table 8 represents the EDAX analysis of all samples under investigation with the surface excess concentrations of each component. The surface excess concentration could be defined as the percent of difference between the actual and theoretical loading of each component over the theoretical loading. From Table 8, it is generally observed that both iron and titanium have larger excess concentrations compared with the -ve and zero values of excess concentration for alumina and cerium, respectively. This result could logically be expected due to the successive impregnation methods used in these preparations. For sample $1 \mathrm{c}$ with $\mathrm{Fe} / \mathrm{Ti}=2.76$, the minimum surface excess concentration of iron oxide was observed, accompanied by a large value for titanium dioxide (351\%), suggesting that iron oxide is nearly totally dissolved or reaches maximum dissolution at this ratio $(\mathrm{Fe} / \mathrm{Ti}=2.76)$.

In Figure 13, the surface excess concentration of iron oxide has been correlated with both $\%$ of $\mathrm{Fe}_{2} \mathrm{O}_{3}$ and the catalytic activity response normalized with respect to iron oxide. From the above figure, it is observed that as \% of $\mathrm{Fe}_{2} \mathrm{O}_{3}$ increases, the surface excess concentration of iron oxide decreases to a minimum at $\%$ of $\mathrm{Fe}_{2} \mathrm{O}_{3}=14.6$ and $\mathrm{Fe} / \mathrm{Ti}=2.76$ and then again increases. In other words, this ratio achieves the maximum dissolving power of iron oxide into titanium dioxide (as shown before from EDAX analysis). The above observation leads us to suppose two catalytic active centers, the surface iron active center (active center 1) and the $\mathrm{Fe}_{2} \mathrm{O}_{3} / \mathrm{TiO}_{2}$ dissolved iron active center (active center 2). From the above figure, it could be summarized 

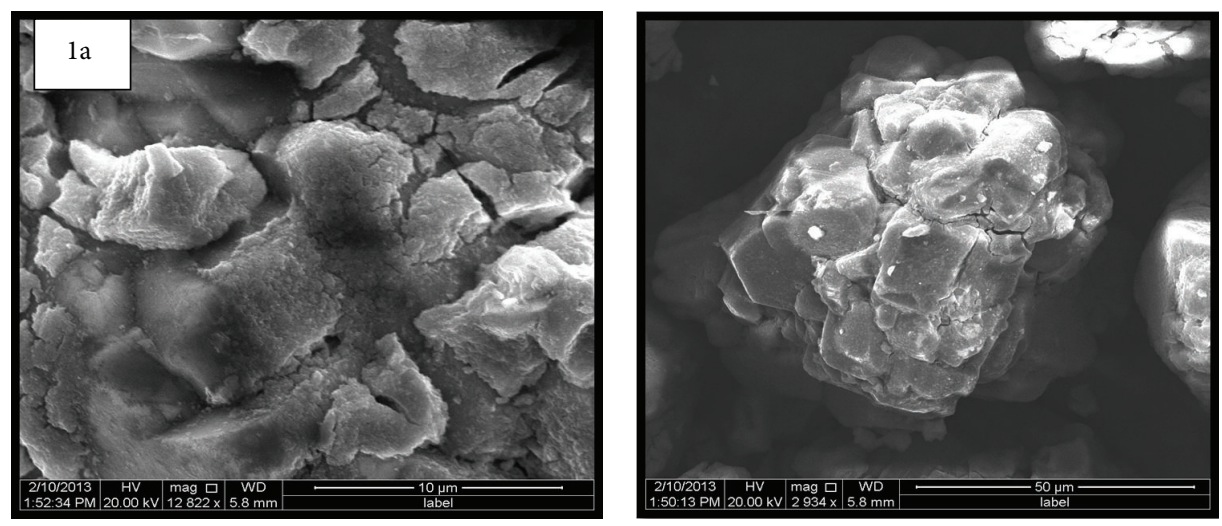

Figure 8: SEM of 1a sample.
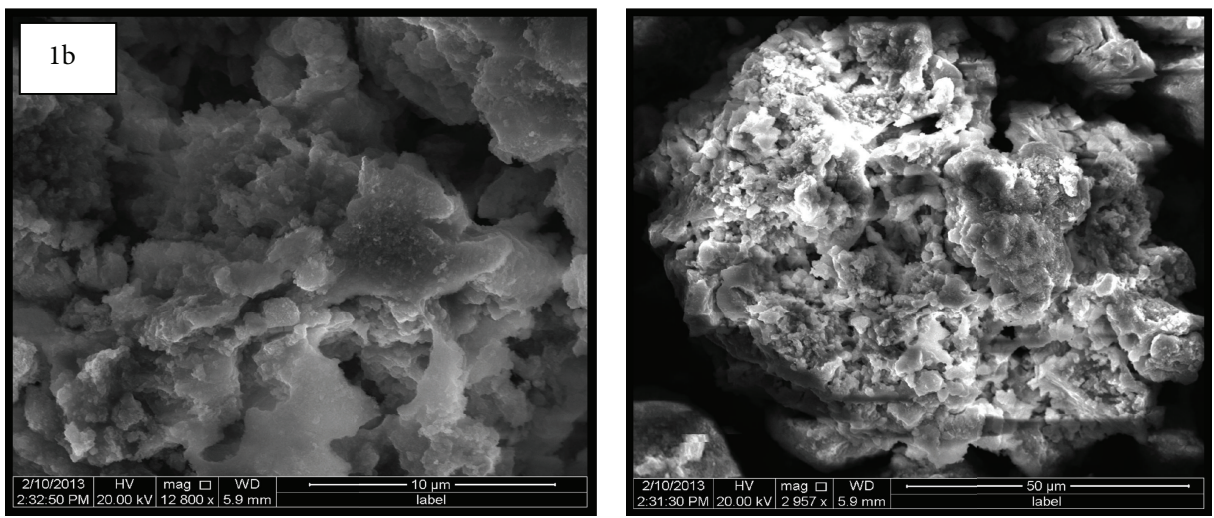

Figure 9: SEM of $1 \mathrm{~b}$ sample.
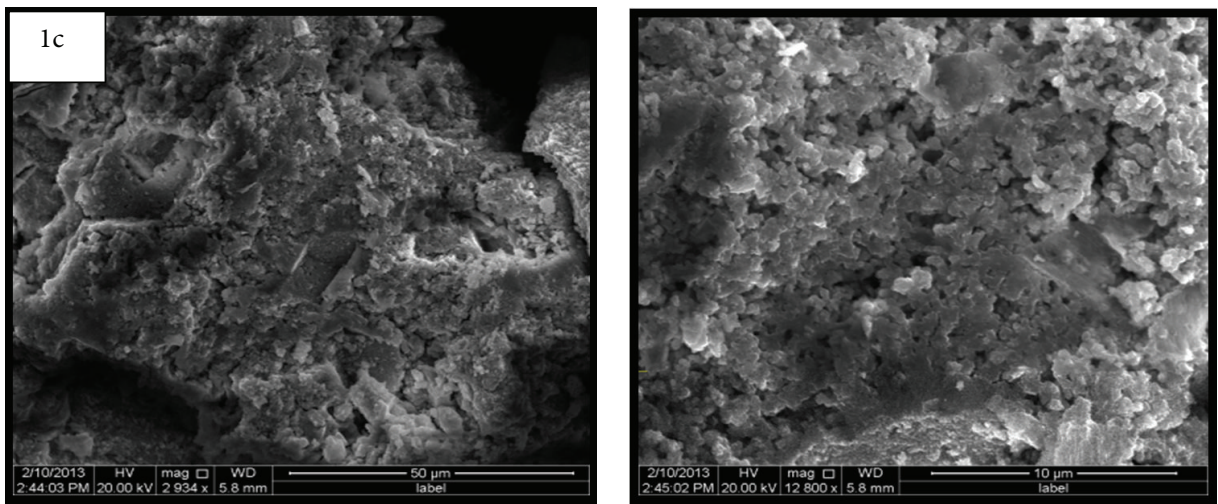

FIgURE 10: SEM of 1c sample.

that as the amount of the second active center increased, evidenced by a decrease of the surface excess concentration of iron oxide, a linear increase was observed till Fe/Ti $=2.76$, after which a nonlinear increase of approximately $43.5 \%$ was observed. This result could be explained by the possibility that before this ratio, the second active site has the larger catalytic activity per unite iron as shown before from Figure 12 with negligible contribution from the first site. After this ratio, the second type of active center is seemed to be having the big contribution in catalytic activity.

3.2. ESR Spectra. The ESR spectra of samples la and 1d was shown in Figure 14.

It was reported that the peaks at $g=2.2$ are due to surface free iron oxide [24]. It was observed that higher loading of iron (sample 1d) showed lower amount of surface 

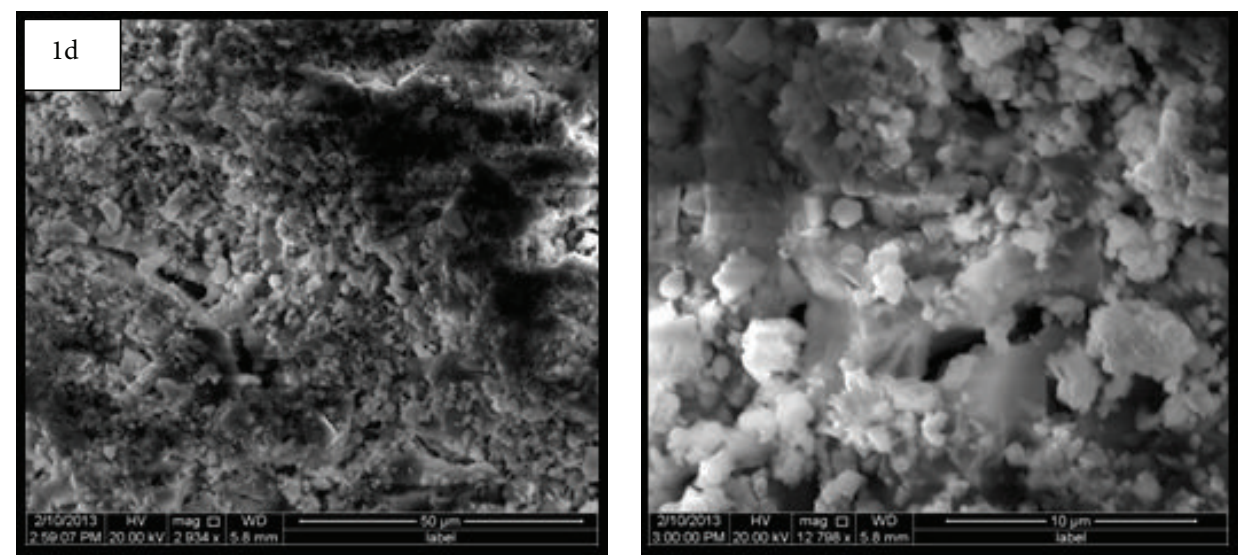

FIGURE 11: SEM of 1d sample.

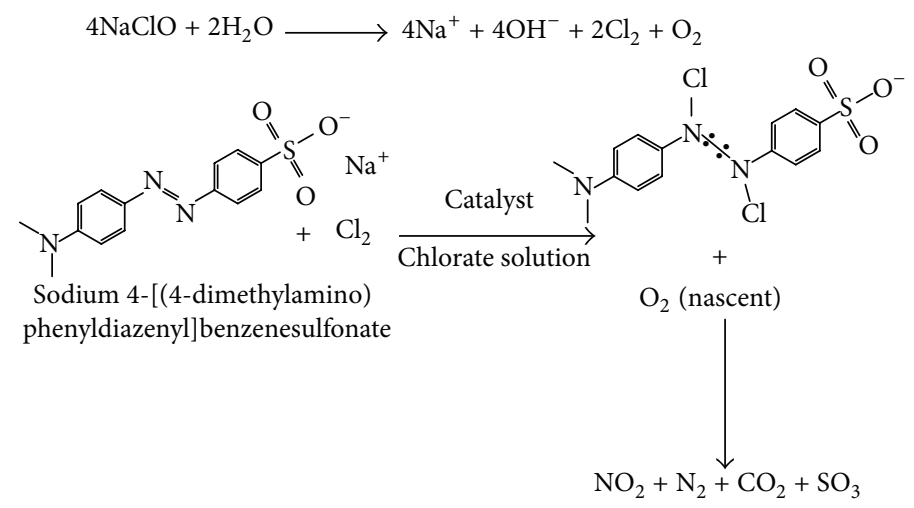

SCHeme 1

iron which agrees with the EDX analysis that this sample showed minimum surface excess concentration while the lower amount (sample la) showed higher amount of surface iron. These results confirm our previous assumption of presence of two active centers of iron oxide.

3.3. Mechanism of Decomposition Using Singlet Oxygen. The catalytic decomposition of catalyst with chlorate solution and oxygen is much higher than the catalytic decomposition of the chlorate solution alone, and passing oxygen over the catalyst in the absence of chlorate does not promote decomposition.

The previous results could be explained in the light of the mode of decomposition of the dye. Providing oxygen without chlorate, even in the presence of a catalyst, does not induce decomposition because molecular oxygen is stable under these conditions, and it is very difficult to decompose the dye at room temperature.

In the presence of chlorate solution (5\% sodium hypochlorite), decomposition will occur according to Scheme 1.

The nascent oxygen produced in the previous equation could be used in the oxidation of the organic dye, and the $\mathrm{Cl}_{2}$ produced could also decolorize the dye [25]. In the combined presence of the catalyst, oxygen, and chlorate, a sudden effervescence of a huge amount of gases occurs, and decolorization can be visually observed in only a few minutes. This result can only be explained by assuming that singlet oxygen is produced. In order to confirm the decomposition of the dye TOC was measured and all samples approache zero TOC indicating that dye is not only decolorized but also totally decomposed.

\section{Conclusions}

From the above study the following conclusions could be drawn:

(1) Catalytic decomposition of organic dye can be performed with high efficiency using a Fe/Ce/Ti/alumina system.

(2) The study of the effect of each component normalized to the others leads us to conclude that iron dissolved into titanium dioxide form the main contributed active centers in this process. The activities of each active center have been correlated to the Fe/Ti ratios. 

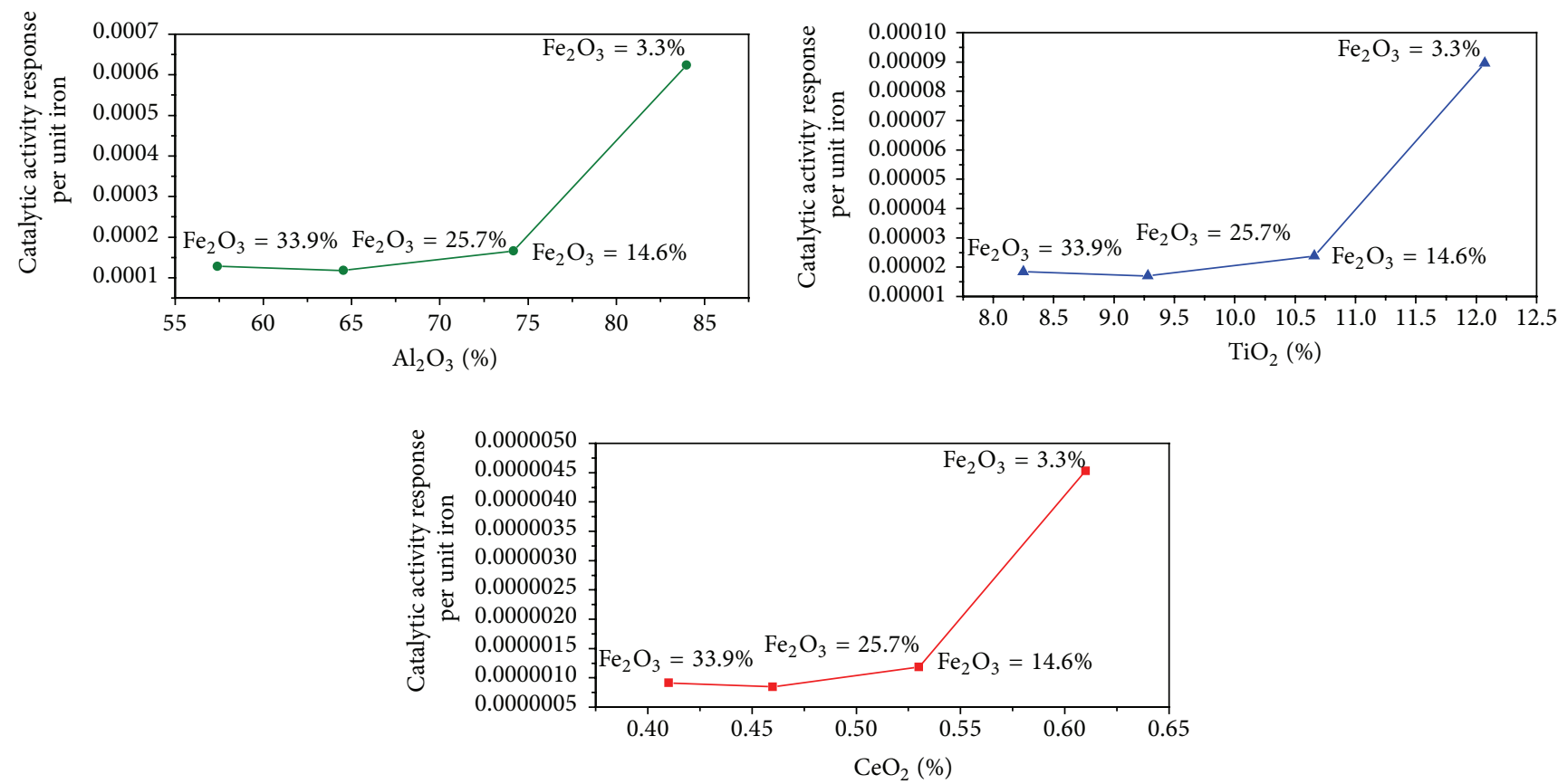

FIGURE 12: Effect of $\%$ composition of $\mathrm{CeO}_{2}, \mathrm{TiO}_{2}$, and $\mathrm{Al}_{2} \mathrm{O}_{3}$ on the catalytic activity per unite iron oxide.

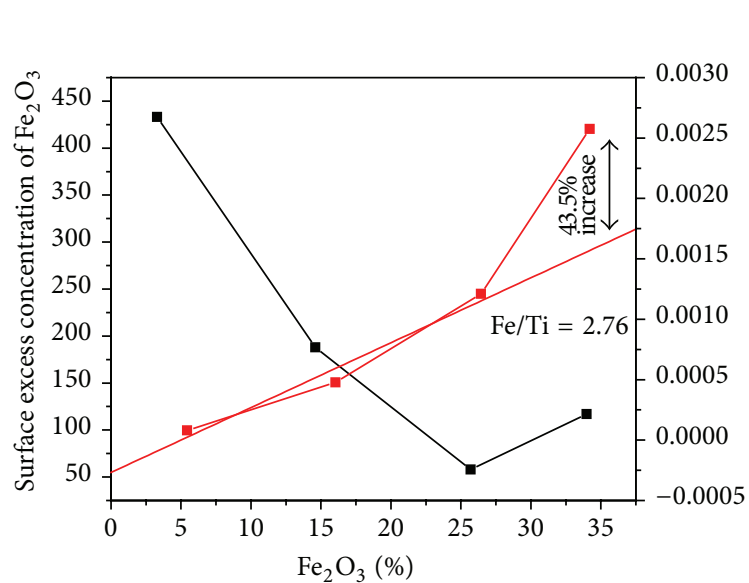

\begin{tabular}{|c|c|c|}
\hline Adj. $R^{2}$ & 0.93904 & \\
\hline & & Standard error \\
\hline ?\$OP:A $=1$ & Intercept & $-1.4253 E-41.53309 E-4$ \\
\hline$? \$ O P: A=1$ & Slope & $5.03567 E-58.92829 E-6$ \\
\hline
\end{tabular}

FIgURE 13: The surface excess concentration of iron oxide has been correlated with both $\% \mathrm{Fe}_{2} \mathrm{O}_{3}$ and catalytic activity response normalized with respect to iron oxide.

(3) The surface study showed that we have two iron active centers, one at the surface and the other dissolved in titanium dioxide.

(4) The dissolving power of iron into titanium dioxide reaches maximum at Fe/Ti mole ratio of 2.76 .

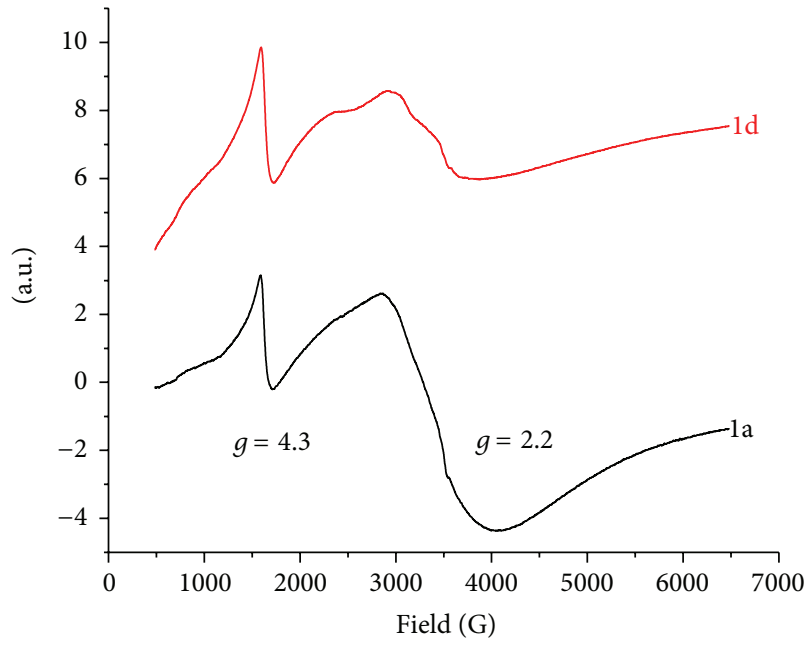

FIGURE 14: ESR of 1a and 1d samples.

(5) The activities of each active center have been correlated to the $\mathrm{Fe} / \mathrm{Ti}$ ratios.

(6) The ceria, alumina, and titanium oxide could help in increasing the catalytic activity of surface active site of iron oxide.

\section{Conflict of Interests}

The authors declare that there is no conflict of interests regarding the publication of this paper. 


\section{References}

[1] C. I. Pearce, J. R. Lloyd, and J. T. Guthrie, "The removal of colour from textile wastewater using whole bacterial cells: a review," Dyes and Pigments, vol. 58, no. 3, pp. 179-196, 2003.

[2] F. P. Van der Zee and S. Villaverde, "Combined anaerobicaerobic treatment of azo dyes-a short review of bioreactor studies," Water Research, vol. 39, no. 8, pp. 1425-1440, 2005.

[3] U. G. Akpan and B. H. Hameed, "Parameters affecting the photocatalytic degradation of dyes using $\mathrm{TiO}_{2}$-based photocatalysts: a review," Journal of Hazardous Materials, vol. 170, no. 2-3, pp. 520-529, 2009.

[4] B. Merzouk, B. Gourich, A. Sekki, K. Madani, C. Vial, and M. Barkaoui, "Studies on the decolorization of textile dye wastewater by continuous electrocoagulation process," Chemical Engineering Journal, vol. 149, no. 1-3, pp. 207-214, 2009.

[5] X. Lu, B. Yang, J. Chen, and R. Sun, "Treatment of wastewater containing azo dye reactive brilliant red $\mathrm{X}-3 \mathrm{~B}$ using sequential ozonation and upflow biological aerated filter process," Journal of Hazardous Materials, vol. 161, no. 1, pp. 241-245, 2009.

[6] P. A. Ramalho, M. H. Cardoso, A. Cavaco-Paulo, and M. T. Ramalho, "Characterization of azo reduction activity in a novel ascomycete yeast strain," Applied and Environmental Microbiology, vol. 70, no. 4, pp. 2279-2288, 2004.

[7] H. Kusic, N. Koprivanac, and L. Srsan, "Azo dye degradation using Fenton type processes assisted by UV irradiation: a kinetic study," Journal of Photochemistry and Photobiology A: Chemistry, vol. 181, no. 2-3, pp. 195-202, 2006.

[8] A. B. Dos Santos, F. J. Cervantes, and J. B. van Lier, "Review paper on current technologies for decolourisation of textile wastewaters: perspectives for anaerobic biotechnology," Bioresource Technology, vol. 98, no. 12, pp. 2369-2385, 2007.

[9] H.-Y. Shu and M.-C. Chang, "Decolorization effects of six azo dyes by $\mathrm{O}_{3}, \mathrm{UV} / \mathrm{O}_{3}$ and $\mathrm{UV} / \mathrm{H}_{2} \mathrm{O}_{2}$ processes," Dyes and Pigments, vol. 65, no. 1, pp. 25-31, 2005.

[10] M. A. Behnajady, N. Modirshahla, and H. Fathi, "Kinetics of decolorization of an azo dye in UV alone and $\mathrm{UV} / \mathrm{H}_{2} \mathrm{O}_{2}$ processes," Journal of Hazardous Materials, vol. 136, no. 3, pp. 816-821, 2006.

[11] J. Levec and A. Pintar, "Catalytic wet-air oxidation processes: a review," Catalysis Today, vol. 124, no. 3-4, pp. 172-184, 2007.

[12] A. K. Kondru, P. Kumar, and S. Chand, "Catalytic wet peroxide oxidation of azo dye (Congo red) using modified Y zeolite as catalyst," Journal of Hazardous Materials, vol. 166, no. 1, pp. 342347,2009 .

[13] Y. S. Ok, J. E. Yang, Y.-S. Zhang, S.-J. Kim, and D.-Y. Chung, "Heavy metal adsorption by a formulated zeolite-Portland cement mixture," Journal of Hazardous Materials, vol. 147, no. 1-2, pp. 91-96, 2007.

[14] S. K. Pitcher, R. C. T. Slade, and N. I. Ward, "Heavy metal removal from motorway stormwater using zeolites," Science of the Total Environment, vol. 334-335, pp. 161-166, 2004.

[15] C. Wang, J. Li, X. Sun, L. Wang, and X. Sun, "Evaluation of zeolites synthesized from fly ash as potential adsorbents for wastewater containing heavy metals," Journal of Environmental Sciences, vol. 21, no. 1, pp. 127-136, 2009.

[16] F. Ji, C. Li, B. Tang, J. Xu, G. Lu, and P. Liu, "Preparation of cellulose acetate/zeolite composite fiber and its adsorption behavior for heavy metal ions in aqueous solution," Chemical Engineering Journal, vol. 209, pp. 325-333, 2012.

[17] M. E. Jenkin and K. C. Clemitshaw, "Ozone and other secondary photochemical pollutants: chemical processes governing their formation in the planetary boundary layer," Atmospheric Environment, vol. 34, no. 16, pp. 2499-2527, 2000.

[18] T. Mori, M. Takahashi, H. Nakajima, T. Fujimoto, and M. Watanabe, "Synthesis and photo-catalytic property of a hollandite-type compound $\left(\mathrm{K}_{2} \mathrm{Ga}_{2} \mathrm{Sn}_{6} \mathrm{O}_{16}\right)$," Journal of the European Ceramic Society, vol. 26, no. 4-5, pp. 583-587, 2006.

[19] G. Busca, M. A. Larrubia, L. Arrighi, and G. Ramis, "Catalytic abatement of $\mathrm{NO}_{x}$ : chemical and mechanistic aspects," Catalysis Today, vol. 107-108, pp. 139-148, 2005.

[20] S. S. Watson, D. Beydoun, J. A. Scott, and R. Amal, “The effect of preparation method on the photoactivity of crystalline titanium dioxide particles," Chemical Engineering Journal, vol. 95, no. 1, pp. 213-220, 2003.

[21] P. Ratnasamy, D. Srinivas, and H. Knözinger, "Active sites and reactive intermediates in titanium silicate molecular sieves," Advances in Catalysis, vol. 48, pp. 1-169, 2004.

[22] K.-W. Kim, E.-H. Lee, D.-Y. Chung et al., "Manufacture characteristics of metal oxide-hydroxides for the catalytic decomposition of a sodium hypochlorite solution," Chemical Engineering Journal, vol. 200-202, pp. 52-58, 2012.

[23] F. M. P. R. Van Laar, F. Holsteyns, I. F. J. Vankelecom, S. Smeets, W. Dehaen, and P. A. Jacobs, "Singlet oxygen generation using PDMS occluded dyes," Journal of Photochemistry and Photobiology A: Chemistry, vol. 144, no. 2-3, pp. 141-151, 2001.

[24] E. Z. Hegazy, I. H. Abd El Maksod, and R. M. M. Abo El Enin, "Preparation and characterization of $\mathrm{Ti}$ and $\mathrm{V}$ modified analcime from local kaolin," Applied Clay Science, vol. 49, no. 3, pp. 149-155, 2010.

[25] S. A. Kosa, "The use of a nanoscale copper catalyst in the catalytic decomposition of water polluted with organic dyes," Journal of Nanomaterials, vol. 2013, Article ID 562830, 4 pages, 2013. 

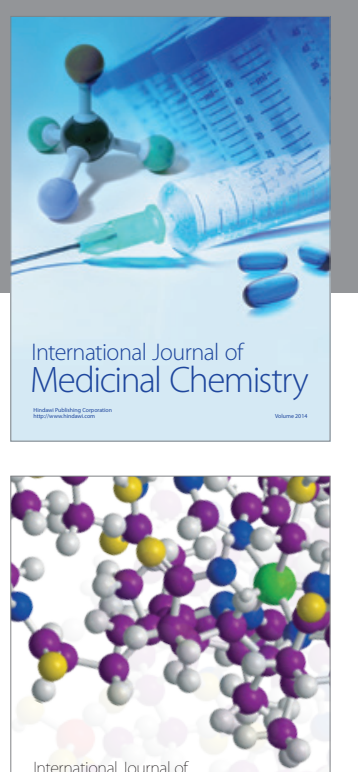

Carbohydrate Chemistry

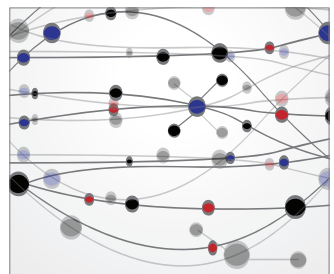

The Scientific World Journal
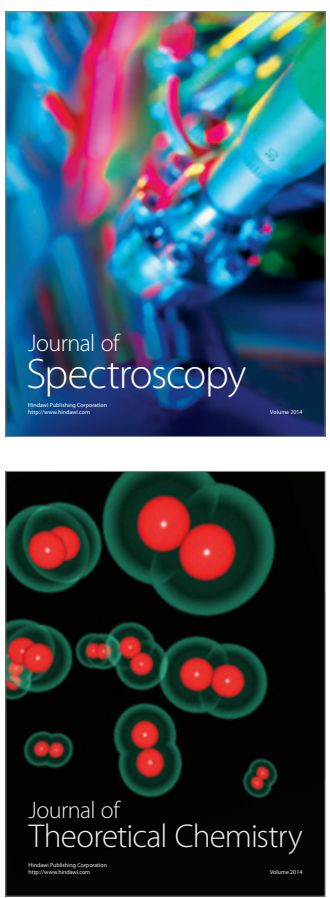
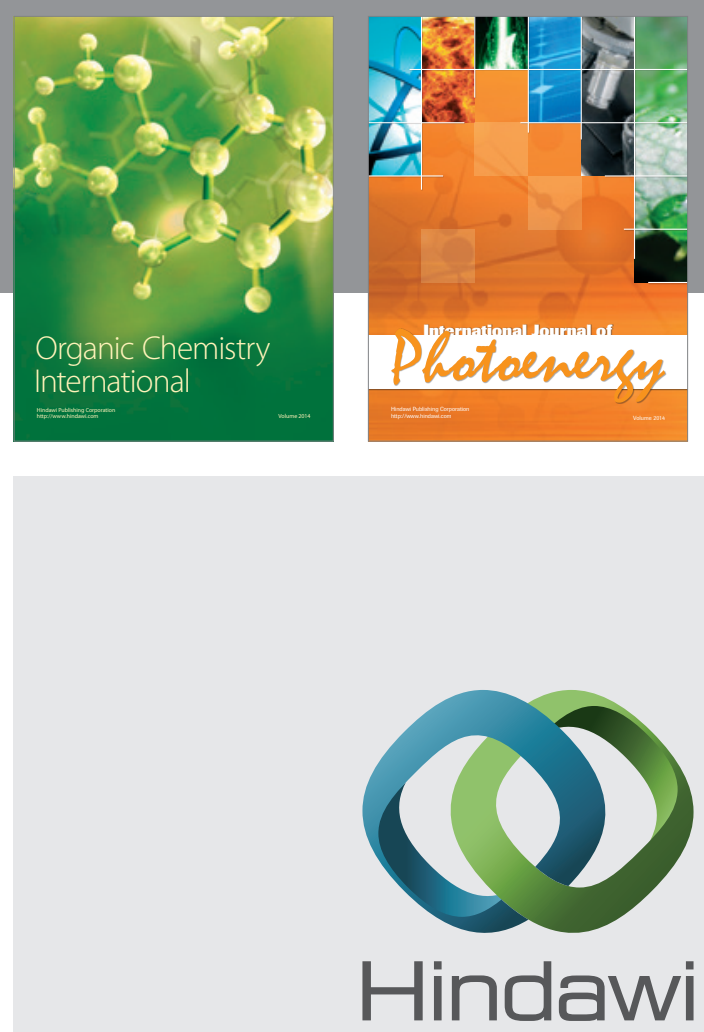

Submit your manuscripts at

http://www.hindawi.com

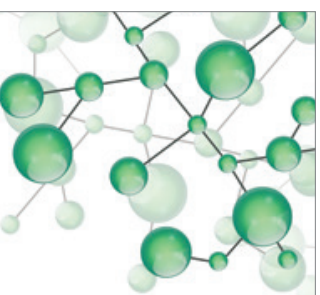

International Journal of

Inorganic Chemistry

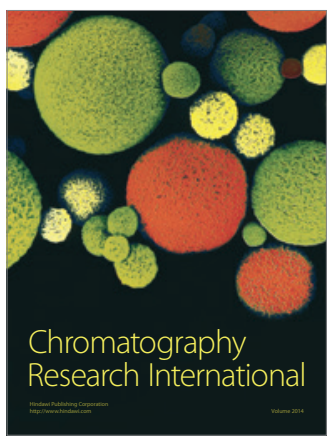

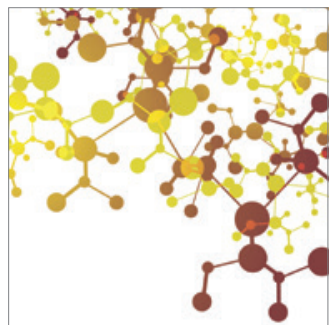

Applied Chemistry
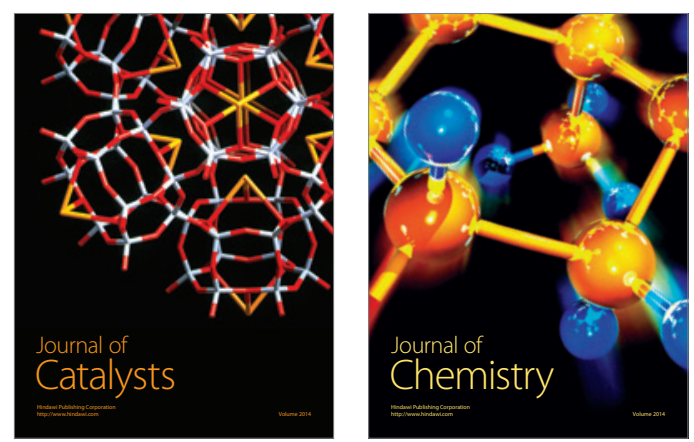
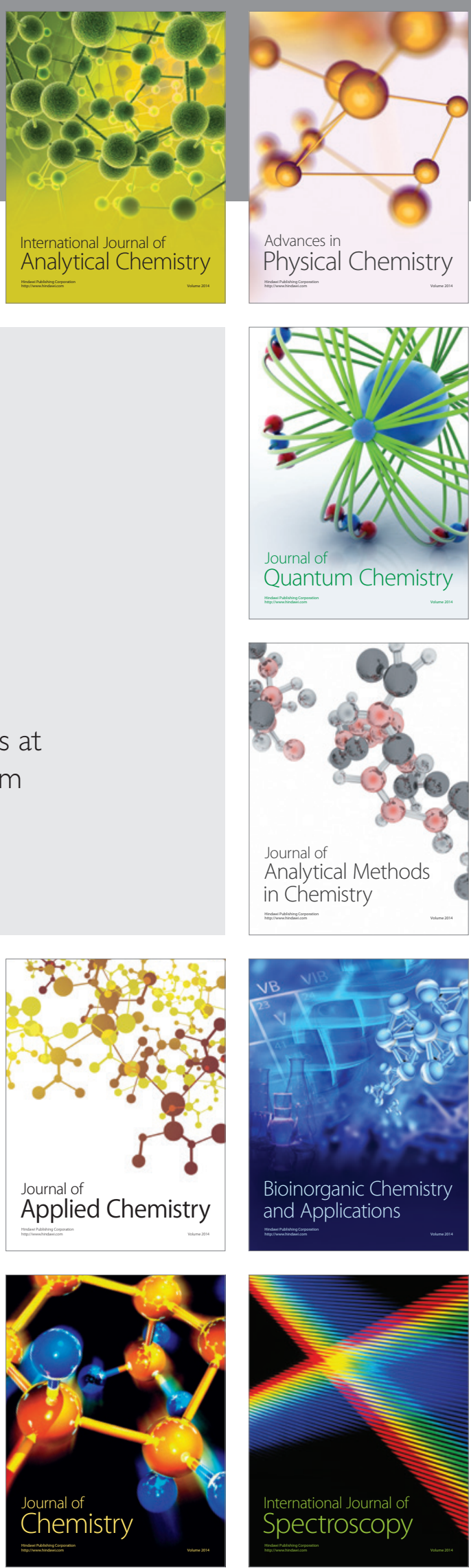